\title{
Horse Allergy: Curly Horses Allow Horse Allergic Riders To Ride Again An Observational Study
}

\author{
Pferdeallergie: Curly Horses erlauben es pferdeallergischen Reitern wieder zu reiten \\ Eine Beobachtungsstudie
}

Authors

Institutions
W. Mitlehner ${ }^{1}$, H. C. Mitlehner ${ }^{2}$, B. Niggemann ${ }^{3}$

${ }^{1}$ Private Medical Practice for Pneumology, Internal Medicine, Allergology, Klappholz

${ }^{2}$ Data management/Biostatistics, Berlin

${ }^{3}$ University Children's Hospital Charité, Dept. of Pediatric Pneumology and Immunology, Berlin received $\quad 8.8 .2015$

accepted after revision 13.10.2015

Bibliography Dol http://dx.doi.org/ 10.1055/s-0034-1393396 Pneumologie 2015; 69: 711-718

(c) Georg Thieme Verlag KG Stuttgart · New York ISSN 0934-8387

\section{Corresponding author} Dr. med. Wolfgang Mitlehner

Zur Schulkoppel 2 24860 Klappholz Germany

wo-mitlehner@t-online.de

\section{Abstract $\nabla$}

To test the hypothesis that so called hypoallergenic horses (Curly horses) allow horse allergic riders to ride again, we investigated 40 horse allergic riders in a period of 37 months.

Methods: We tested these patients (pts.) by skin prick test (SPT) with different non-curly and Curly horses and studied the riding hours and horse brushing by measurements of peak expiratory flow (PEF) and Tiffeneau tests (FEV1) as well as peak nasal inspiratory flow (PNIF) over 12 months. The results in 37/40 pts. showed no relevant reactions of the lower airways or nasal flow. Only in 3/40 patients an initial significant fall of FEV1 was observed, reversed by a single inhalation of salbutamol and not repeated despite further riding contact. In contrast to other allergic events (e.g. baker's asthma) a further and regular contact with these horses abolished the mild allergic reactions of the start period of contact. This may be due to hypoallergenic properties of these horses, whose test material produces weaker reactions in the SPT than that of normal horses. After a period of three years, a loss of reactivity to normal horses could be confirmed in some of the riders.

Conclusion: The tested purebreed Curly horses may be a suitable alternative for horse allergic riders if the methodological precautions of this study are followed.

\section{Zusammenfassung \\ $\nabla$}

Um die Hypothese zu testen, dass die sogenannten hypoallergenen Pferde (Curly Horses) es pferdeallergischen Reitern ermöglichen, wieder zu reiten, untersuchten wir 40 pferdeallergische Reiter in einem Zeitraum von 37 Monaten.

Methoden: Wir testeten diese Patienten (Pts.) mit einem Prick-Test (SPT) mit verschiedenen Materialien von Nicht-Curly-Pferden und Curly Horses und untersuchten die Effekte der Reitstunden und des Pferdebürstens durch Messungen des PeakFlow (PEF) und Tiffeneau-Tests (FEV1) sowie zusätzlich den Naseninspirationsflow (PNIF) über 12 Monate.

Ergebnisse: 37 der 40 Pts. zeigten keine relevanten Reaktionen der unteren Atemwege oder des Nasenflusses. Nur bei 3/40 Patienten wurde anfangs ein deutlicher Rückgang der FEV1 beobachtet, der durch eine einzige Inhalation von Salbutamol beseitigt wurde und sich trotz weiterer Reitkontakte nicht wiederholte. Im Gegensatz zu anderen allergischen Erkrankungen (z. B. Bäckerasthma) führte der weitere und regelmäßige Kontakt zu diesen Pferden zu einer Beseitigung der leichten allergischen Reaktionen der Startperiode des Kontaktes. Dies kann auf hypoallergene Eigenschaften dieser Pferde zurückgeführt werden, deren Testmaterial schwächere Reaktionen im SPT als Material normaler Pferden produzierte. Nach einem Zeitraum von drei Jahren konnte ein Verlust an Reaktivität gegenüber normalen Pferden bei einigen der Reiter nachgewiesen werden. Fazit: Die getesteten reinrassigen Curly Horses können eine geeignete Alternative für pferdeallergische Reiter sein, wenn die methodischen Vorsichtsmaßnahmen dieser Studie befolgt werden. 


\section{Introduction}

$\nabla$

Allergy to mammalian animals is an underrated topic. Sensitization to cats and dogs is often tested by standard skin prick test (SPT). Horse allergy is often a result of horse contact [1-4] or due to cross reactivity [5-8] but not often tested in standard SPT despite its high frequency [9-12]. In the case of symptomatic horse allergy the standard recommendation is to avoid horse contact $[13,14]$ or immunization against horses $[15,16]$. One recent report [18] and reports from Curly Horses enthusiasts [1921] claimed the hypoallergenic properties of these horses render them suitable for patients with horse allergy. In a first clinical observational pilot study we examined the effects of Curly Horses on horse allergic riders [22]. The aim of this study was to test the hypothesis of hypoallergenicity of Curly Horses in a group of 40 symptomatic horse allergic riders over a period of 37 months.

\section{Methods}

$\nabla$

Patients with a history of allergy against horses who had given up riding because of symptomatic allergy (rhinitis, asthma, eczema) to horses volunteered for the study following media coverage of the research. Patients gave written consent for the horse contact and data collection.

The patients were clinically investigated concerning their lung function prior to horse contact: medical history, spirometry, or if spirometry could not be clearly interpreted owing to cooperation problems - bodyplethysmography. Subsequently, an SPT was carried out for horse (Bencard ${ }^{\circledR}$, Munich, Germany), histamine, and saline as control. A skin prick test with mixtures of the dander and the horse hairs of the curly mares followed. The same assistant always carried out, assessed, and photographically documented the prick tests in the same manner. The test material was obtained from individual brushes of the mares and prepared according to a previously published method $[23,24]$ : a fingertip of the cutup hair and dander sample, suspended in $1 \mathrm{ml} 0.9 \%$ sodium chloride solution, was used. After positioning the material on the forearm skin we used a skin prick lancet and removed the material after 60 - $90 \mathrm{sec}$. For control reasons we used hair probes of a German riding pony prepared in the same way as in the case of curly hair.

The horses we used for tests were:

1. Horse 1: ABC Curly (P2563) straight Curly, Canada

2. Horse 2: ABC Curly (3975) microcurl Curly, Sweden

3. Horse 3: ABC Curly (4049) macrocurl Curly, Austria (07 - 2012)

4. Horse 4: ABC Curly (4056) microcurl Curly, Germany

(born 2012/included 2013)

5. Horse 5: German riding pony (control for self-processed prick material)

We used only ABC Curlies to obtain a relatively pure breeding line because Curly horses are listed in the ABCR register (American Bashkir Curly Horse Registry) by closed studbooks.

No other horses than Curly horses were present in the stable. The German riding pony was located in another stable, and no other horses were located around the stable in a distance of more than 500 meters [25].

For each case of allergy testing, the influence of concomitant medication was excluded (antihistamines, steroids, leukotriene synthesis inhibitors). Concomitant medications for the treatment of asthma or rhinitis induced by other allergens than horses were continued.
Table 1 Baseline patient characteristics $(n=40)$

\begin{tabular}{|l|c|}
\hline Age (y) & $17.6( \pm 12.7)$ \\
\hline Sex (f/m) & $37 / 3$ \\
\hline Duration of allergic bronchial asthma/rhinitis & $11.5( \pm 9.8)$ \\
\hline Underlying allergic disease & 32 \\
\hline Allergic bronchial asthma & 40 \\
\hline Allergic rhinoconjunctivitis & 8 \\
\hline Atopic eczema & \\
\hline Allergic symptoms at horse contact (history) & 25 \\
\hline Bronchial asthma & 40 \\
\hline Allergic rhinoconjunctivitis & 12 \\
\hline Atopic eczema & 1 \\
\hline Anaphylaxis & \\
\hline Allergies other than horse & 34 \\
\hline Pollen & 25 \\
\hline House dust & 14 \\
\hline Mold & 29 \\
\hline Furry animal & 14 \\
\hline Food & \\
\hline Current treatment of patients with & 23 \\
\hline ICS & 33 \\
\hline SABA & 7 \\
\hline LABA & 28 \\
\hline Antihistamines & 3 \\
\hline Leukotriene inhibitors & 10 \\
\hline Topical nasal steroids & \\
\hline Other (DNCG, Homeopathy) & \\
\hline
\end{tabular}

$\mathrm{ICS}=$ inhaled steroids, SABA = beta 2 mimetics short, LABA = beta 2 mimetics long, DNCG = cromoglycate,

$y=$ years, $f=$ female; $m=$ male

The patients were only exposed to the Curly horses if PEF and FEV1 were within normal range.

Subsequently, the patients had contact by riding hours on the horses, comprising one hour riding outside on a swing ground ${ }^{\circledR}$ riding place without brushing. Only in three cases the duration of riding time was 30 minutes because of the fitness of the riders or weather conditions. Later, the contact was intensified: one hour riding followed by $15 \mathrm{~min}$ of horse brushing.

Initially, PEF measurements were performed in 15 min steps before, during and after the first horse contact by Vitalograph 2110 (Vitalograph GmbH, 20257, Hamburg) electronic PEF/FEV1 diary until 9-2014, documented and then prolonged to $30 \mathrm{~min}$ intervals of measurement in the further riding hours. Since 5-2012, we additionally documented the measured FEV1 values and since 9-2013 PNIF by PNIF meter (Clement Clarke). Since 92014, we measured lung function data by Micro LOOP (CareFusion Germany, D-97204, Hoechberg, Germany) for better electronic conservation of the results. Other possible symptoms were also assessed (skin, nose, eyes, and respiration). The main endpoint was a peak flow or FEV1 decrease of more than $20 \%$ of the initial value. If this event occurred treatment with salbutamol was followed immediately. The riding test was also repeated with these patients on the following day or visit. The measurement intervals at these days were 30 minutes.

All patients were rechecked $15 \mathrm{~min}$ after horse contact and after brushing. During the first hours of horse contact, the patients were not allowed to enter the horse stable. This was done to avoid bringing the patients into contact with any other possible influence on their allergy. 
Table 2 Results of horse SPT and correlation to PEF reaction in first riding hour.

\begin{tabular}{|c|c|c|c|c|c|c|}
\hline & $\begin{array}{l}\text { Horse Prick } \\
\text { (Bencard) }\end{array}$ & $\begin{array}{l}\text { Horse 5: German } \\
\text { riding pony }\end{array}$ & $\begin{array}{l}\text { Horse 1: ABC } \\
\text { Curly P2563 }\end{array}$ & $\begin{array}{l}\text { Horse 2: ABC } \\
\text { Curly } 3975\end{array}$ & $\begin{array}{l}\text { Horse 3: ABC } \\
\text { Curly } 4049\end{array}$ & $\begin{array}{l}\text { Horse 4: ABC } \\
\text { Curly } 4056\end{array}$ \\
\hline \multicolumn{7}{|l|}{ SPT } \\
\hline$\varnothing \mathrm{in} \mathrm{mm}$ & 13.18 & 10.61 & 6.48 & 7.48 & 6.15 & 6.22 \\
\hline SD & \pm 5.87 & \pm 5.11 & \pm 4.59 & \pm 5.32 & \pm 5.51 & \pm 2.32 \\
\hline $\mathrm{N}$ & 40 & 28 & 40 & 40 & 33 & 18 \\
\hline \multicolumn{7}{|c|}{ p-value from Wilcoxon rank sum test with continuity correction* } \\
\hline Bencard & & & 0.0000 & 0.0008 & 0.0000 & 0.0002 \\
\hline Horse 5 & & & 0.0003 & 0.0035 & 0.0003 & 0.0008 \\
\hline \multicolumn{7}{|c|}{ SPT and correlation to PEF: Spearman's rank correlation coefficient } \\
\hline$\triangle \mathrm{PEF} 30^{\prime}$ riding & -0.10 & & 0.01 & -0.10 & & \\
\hline$\triangle \mathrm{PEF} 60^{\prime}$ riding & -0.24 & & 0.12 & -0.17 & & \\
\hline$\triangle \mathrm{PEF} 15^{\prime}$ post riding & -0.53 & & -0.06 & -0.29 & & \\
\hline
\end{tabular}

* Wilcoxon test performed to compare self-made Curly SPTs results with self-made riding pony SPTs and industrial SPT. The rejection of the null hypothesis induced that the lasts tend to have significantly larger values than the Curly SPTs. Correlation coefficients was calculated by using the $\triangle$ PEF values from the first visit.

Table 3 All results of mean (+SD) measurements for PEF/FEV1/PNIF.

\begin{tabular}{|llll|}
\hline & Delta PEF & Delta FEV1 & Delta PNIF \\
\hline after $\mathbf{3 0}$ min riding & & & \\
\hline mean & $-0.30 \%$ & $-0.60 \%$ & $7.25 \%$ \\
\hline standard deviation & $10.89 \%$ & 11.46 & $23.37 \%$ \\
\hline $\begin{array}{l}\text { no. of observations } \\
\text { after } \mathbf{6 0} \text { min riding }\end{array}$ & 336 & 283 & 161 \\
\hline mean & $-0.42 \%$ & $-1.21 \%$ & $4.77 \%$ \\
\hline standard deviation & $9.82 \%$ & $10.05 \%$ & $23.96 \%$ \\
\hline no. of observations & 323 & 275 & 157 \\
\hline after $\mathbf{1 5}$ min riding & & & \\
\hline mean & $-1.63 \%$ & $-2.04 \%$ & $2.92 \%$ \\
\hline standard deviation & $9.28 \%$ & $12.03 \%$ & $28.51 \%$ \\
\hline no. of observations & 218 & 168 & 91 \\
\hline after $\mathbf{1 5}$ min brushing & & & \\
\hline mean & $-3.82 \%$ & $-1.64 \%$ & $-8.50 \%$ \\
\hline standard deviation & $11.05 \%$ & $8.48 \%$ & $16.11 \%$ \\
\hline no. of observations & 59 & 39 & 18 \\
\hline
\end{tabular}

\section{Results}

Between 10-2011 and 11-2014 we tested and observed 40 horse allergic patients ( $\bullet$ Table 1 ) which all had given up riding due to inacceptable allergic symptoms at horse contact. In some cases the development of bronchial asthma started after giving up horse contact, i.e. because of allergic rhinoconjunctivitis. This explains why in the anamnestic data in some cases only a rhinoconjunctivitis is reported at horse contact, although a bronchial asthma has been developed afterwards.

The results of SPT are displayed in $\bullet$ Table 2 . These data demonstrate firstly that the "self-made" SPT are comparable to industrial SPT (Bencard ${ }^{\circledR}$ ) in respect to different SPT reactions between "normal" horse and curly horse tests, and secondly that the diameters of wheal testing with the curly probes are significantly smaller than in normal horses $(\mathrm{p}=<0.0000-<0.0035)$. We found no significant difference in the diameter of wheals between the different Curly types: microcurl, macrocurl and straight hair curlies.

The observation of the 40 allergic riders was carried out in 345 horse contact and riding hours (mean $8.6 \pm 10.86$ riding hours). The values at rest before riding or horse contact were in normal ranges for PEF and FEV1.
We found a correlation between the diameter of wheal in industrial SPT and straight curly SPT test to PEF reaction of patients on the curly horses in their first riding and brushing contact ( Table 2). The correlation between SPT and riding on curly horses was much weaker.

\section{PEF $(\bullet$ Table 3, $\bullet$ Fig.1, $\bullet$ Fig. 2)}

The effects of curly contact on PEF of patients was on average minimal: $0.3 \%$ (SD $11 \%$ ) at 30 minutes (data not shown), $-0.42 \%$ $(\mathrm{SD} \pm 9.82)$ at 60 minutes ( Fig.1) and $-1.63 \%( \pm 9.28) 15$ minutes after riding. Brushing these horses leads on average to a decrease in PEF of $-3.82 \%( \pm 11.05)$. However, the curly horse contact induced in 3 cases a decrease in PEF of more than $20 \%-30 \%$ and only in 1 case a decrease of more than $50 \%$. The observed PEF decrease could be eliminated by two puffs of salbutamol and did not replicate at further contacts. On the contrary: the longer the riding contact to the horses lasted (up to 45 riding hours) the weaker was the reaction to the horses ( $\bullet$ Fig. 2 ) in the $11 / 40$ pts who had $\geq 15$ riding hours. The regression of PEF values demonstrates no increase of PEF reaction during the contact to the curly horses over the time ( $\bullet$ Fig. 1 ).

\section{FEV1 ( Table 3, $\bullet$ Fig. 3 )}

The influence of curly horse contact at riding measured by FEV1 was quite similar to the results of PEF: $-0.85 \%( \pm 12 \%)$ at 30 minutes ( Table 3 ), $-1.21 \%( \pm 10 \%)$ after 60 minutes riding ( Fig. 3 ) and $-2.04 \%( \pm 12 \%) 15$ minutes after riding ( Table 3 ). Brushing these horses induced a mean weak decrease of FEV1 of $-1.64 \%$ ( $\pm 8 \%$ ). Table 4 shows the data of patients whose FEV1 values decreased more than $20 \%$ from start measurement as possibly adverse events (cf. adverse events).

\section{PNIF ( Table 3)}

The results of the PNIF measurements we have introduced since 9/2013 are shown in table 3: The effects of curly contact on PNIF are similar to the effects on PEF and show a weak influence on PNIF at 60 riding minutes of average $4.77 \%( \pm 23.96 \%)$ and after riding of mean: $2.92 \%$ ( \pm SD: $28.51 \%)$. 


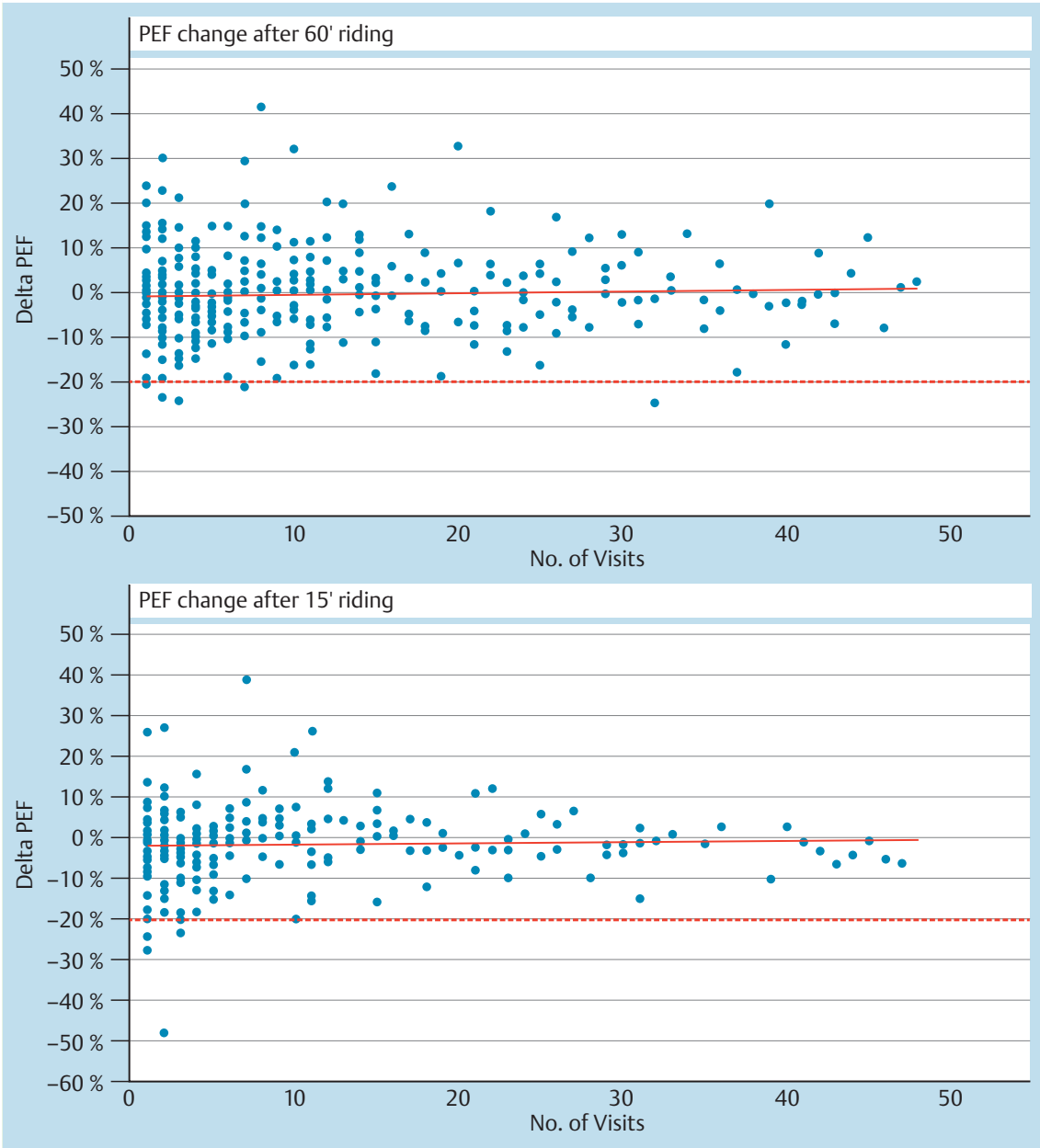

Fig. 1 PEF reaction during and after riding. Delta $\mathrm{PEF}$ is calculated as percentage change in relation to the base value taken before each riding hour. Includes observations from 40 different patients between October 2010 and November 2014. The regression of the 60 ' values is $y=0.0005 x-0.01$ and for the $15^{\prime}$ after riding values is $y=0.0003 x-0.0197$.

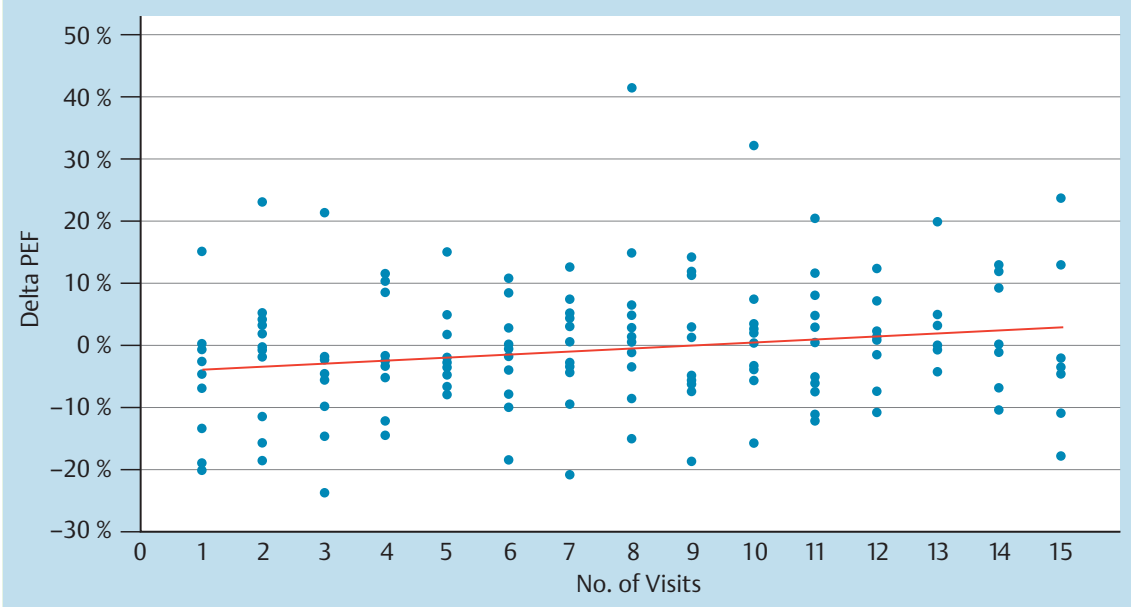

Fig. 2 Relation between the PEF reaction after 60 minutes of riding and the number of visits. Shows the percentage change in relation to the base value taken before each riding hour. Observations taken from the first 15 riding hours of 11 pts. with a minimum of 15 riding hours. The red line results from a linear regression and demonstrates the relation between the number of visits and the changes in PEF after 60 minutes of riding. A t-test results in a slope coefficient (0.0049) significant on the $5 \%$ level is $(\rho=0.012)$.

\section{Adverse events ( $\bullet$ Table 4 )}

We observed a clear reaction to curly horse contact in only three patients. In the other cases of FEV1 decrease we found either a normal PEF (badly performed test, especially in children) or concomitant allergic exposure to pollen in air outside our riding location place. The first patient ( $\mathrm{nr} 2$, 0 Table 4) has had an anamnestic allergic shock after contact with normal horses in the past. Here we found a decrease of PEF of more than $40 \%$, which could be reversed by a double inhalation of salbutamol. A similar reaction did not occur in subsequent riding days ( $\bullet$ Table 4 ).
A second reaction occurred in a pollen allergic patient ( $\mathrm{nr} 11)$ in the end of the riding hour with a decrease of lung function after riding, which was reversed by two puffs of salbutamol. On this day, elder pollen was recorded [26]. Unfortunately this patient did not continue the riding hours due to a lack of time available. In a third patient ( $\mathrm{nr} 35$ ) we observed a clear relationship between the first riding hour and a decrease of FEV1 of $21 \%$ after 60 ' riding and 15 ' after riding of $27 \%$. In the next 1 to 2 following riding days this could not be reproduced. The influence of curly horse on lung function showed a loss of reaction to the horses (๑ Fig. 2). 


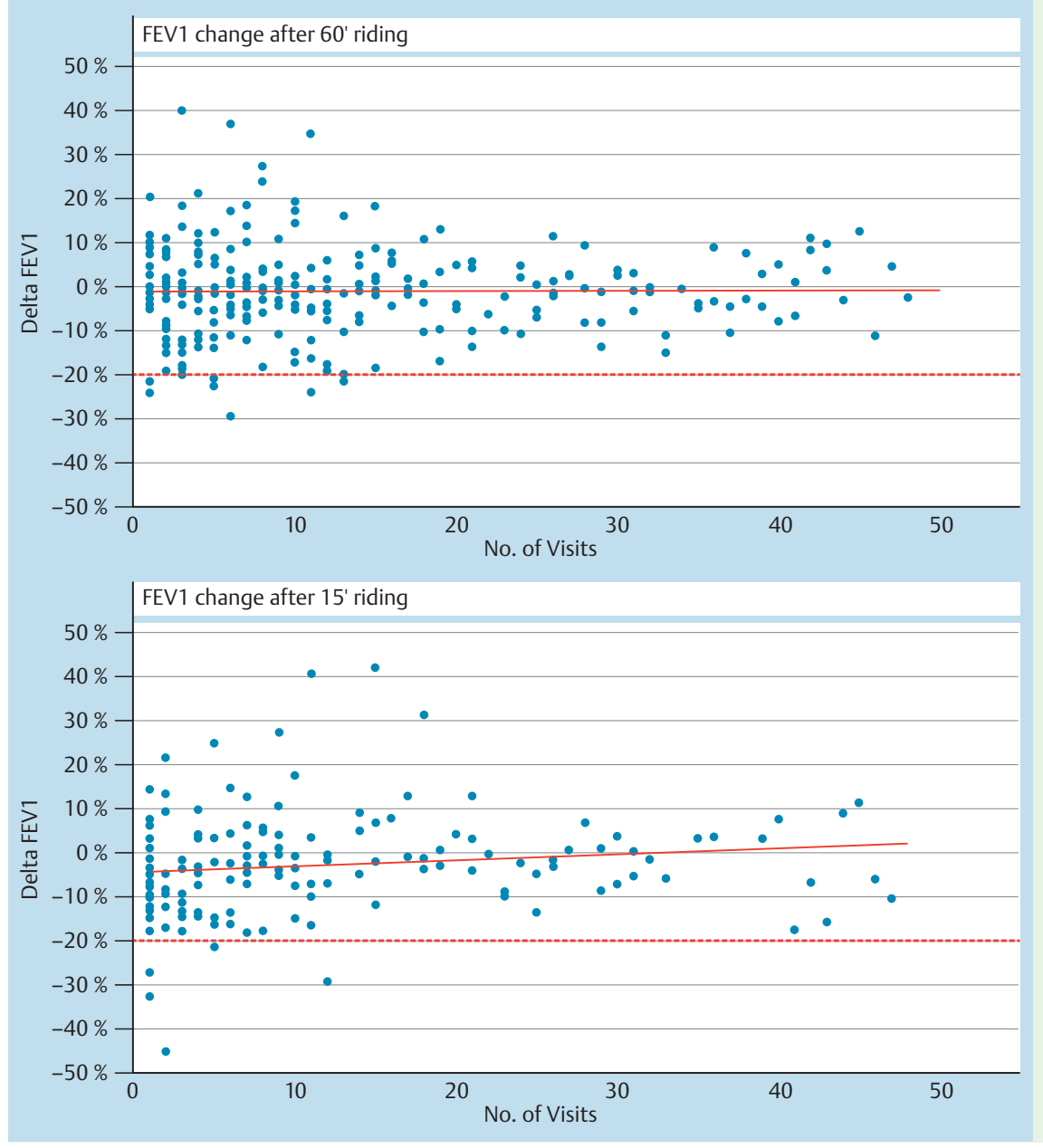

Fig. 3 FEV1 values during and after riding. Delta FEV1 is calculated as percentage change in relation to the base value taken before each riding hour. Includes observations from 33 patients between March 2012 and November 2014. Regression for the 60 ' values is $y=0.0004 x-0.0223$ and for the values 15 ' after riding $y=0.001 x-0.0339$.

\section{Discussion}

\section{Skin Prick Test}

This observational study showed that four ABC-registered Curly horses caused much weaker skin allergic reactions in 40 horseallergic riders than horses of other tested breeds (commercial horse prick allergen extract, German riding pony). To exclude the drawback of self-produced allergy test material we also produced material from a German riding pony. In $\bullet$ Table 2 the selfproduced allergy test wheal of the German riding pony is more close to industrial prick test material than the wheal of the Curly horse material in SPT. It seems that the weaker reaction of curly horse material in SPT results possibly from a lower allergenicity of curly horses [17], but this remains to be investigated in the future because Felix et al. refused a lower allergenicity in their study [27].

In addition, the origin of the two Bashkir Curly horses in the study of Felix [27] had not been defined according to the register of origin for Curly horses. Thus, it is not clear which horses were actually studied. The work also suffers from methodological flaws, since the results list only two Bashkir Curly horses and a Russian Bashkir horse, the latter from a breed that is genetically unrelated to the American Curly horse [27]. In contrast to Felix [27], Kürschner and Jugert [18] detected a reduced amount of allergens in Curly horse epithelia in a single Western blot test. From our test results a mean lower allergenic potential of the investigated Curly horses can be concluded.
In the present study no correlation between the property of Curly hair (microcurl, macrocurl and straight Curly hair) and the allergic reactions of patients could be established between the three mares and the one gelding.

The reason for the low allergic potential of Curly horses seems neither to be linked with the degree of curls of the horses nor with the severity of the riders' allergic anamnesis. The presence of rhinoconjunctivitis or previous allergic asthma in the anamnesis was not relevant for the reaction in the SPT test.

The so-called "horses with curls" are attributed with hypoallergenicity. This judgement is not based on a scientific clinical study but only on a single case study [18] and the experience of riders (www.abcregistry.org; www.curlyhorses.org).

The origin of the Curly horse breed is not clear [19]. They may originate from Russian horses (Lokai not Bashkir), from Latin American/Spanish horses [19], or may even be an indigenous Northern American breed.

To obtain a relatively pure breed by closed studbooks, Curly horses are listed in the ABCR register (American Bashkir Curly Horse Registry). After 2000, Curly horses are also registered in the ICHO register (International Curly Horse Organization), allowing breeding to produce a larger variability of the exterior characteristics.

The other features of Curly horses are described elsewhere (www.abcregistry.org; www.curlyhorses.org).

Sponenberg showed that the genetic property of the American Curly horse to generate curls is a dominant trait $[19,28]$. Using polarization stress analysis, Farrell found that curly hairs exist at 
Table 4 Events of FEV1 decrease of $>20 \%$.

\begin{tabular}{|c|c|c|c|c|c|}
\hline Patient nr & Date & $\begin{array}{l}\text { Pollen } \\
\text { flight }\end{array}$ & $\begin{array}{l}\text { Pollen } \\
\text { relevance }\end{array}$ & Remarks & $\begin{array}{l}\text { Assessment of } \\
\text { reaction to horse }\end{array}$ \\
\hline 1 & 01.03 .2014 & $A+H$ & yes & $\begin{array}{l}\text { brushing in stable because of bad weather outside } \\
\text { known allergy against } B+G+M+H e+R+A+H \text { (stable) } \\
\text { pollen. }\end{array}$ & no \\
\hline 2 & 15.10 .2011 & no & no & $\begin{array}{l}\text { reaction after horse brushing, reversed by } 2 \text { puff } \\
\text { salbutamol: anamnestic allergic shock to horse }\end{array}$ & yes \\
\hline 10 & 30.09 .2013 & no & no & $\begin{array}{l}\text { at } 30 \text { ' measurement increase of PEF and decrease } \\
\text { of FEV1: bad performance }\end{array}$ & no \\
\hline 11 & 13.03.2014 & $\mathrm{A}+++/ \mathrm{H}$ & possible & $\begin{array}{l}\text { known allergy against } A+\mathrm{H} \text { pollen reaction after } \\
60 \text { 'riding; } 2 \text { puff salbutamol reversed the reaction }\end{array}$ & yes \\
\hline 16 & $\begin{array}{l}31.01 .2013 \\
30.06 .2014 \\
06.07 .2013\end{array}$ & $\begin{array}{l}\text { no } \\
\mathrm{R} / \mathrm{G} / \mathrm{He} \\
\mathrm{G} / \mathrm{R} / \mathrm{He}+++\end{array}$ & $\begin{array}{l}\text { no } \\
\text { no } \\
\text { no }\end{array}$ & $\begin{array}{l}\text { at } 30^{\prime} \text { measurement increase of PEF but decrease } \\
\text { of FEV } 1 \text { badly performed test. } \\
\text { the decrease at } 30^{\prime} \text { was relative to a start FEV } 1 \text { of } \\
146 \% \text { of pred. } \\
\text { at } 60^{\prime} \text { decrease of FEV } 1>20 \% \text {, not of PEF }\end{array}$ & no \\
\hline 17 & 24.05 .2013 & G & no & $\begin{array}{l}\text { FEV } 1 \text { decrease of more than } 20 \% \text { at } 30 \text { ' riding while } \\
\text { unchanged PEF at } 30^{\prime} \text { badly performed FEV } 1 \text { test }\end{array}$ & no \\
\hline 18 & 29.09 .2014 & no & no & $\begin{array}{l}\text { at second contact to curly horse } \\
\text { relevant decrease after riding: either reaction to } \\
\text { horse or exercise asthma }\end{array}$ & yes/no \\
\hline 19 & $\begin{array}{l}08.06 .2013 \\
02.08 .2013\end{array}$ & $\begin{array}{l}\mathrm{G} / \mathrm{R} / \mathrm{He} \\
\mathrm{M}+++/ \mathrm{G}\end{array}$ & no & $\begin{array}{l}\text { badly performed FEV1 test, normal PEF } \\
\text { badly performed FEV1 test, normal PEF }\end{array}$ & no \\
\hline 22 & 17.05 .2013 & $\mathrm{O}+++/ \mathrm{B} / \mathrm{G}$ & no & badly performed FEV1 test, normal PEF & no \\
\hline 31 & 22.07 .2014 & $\mathrm{G} / \mathrm{He} / \mathrm{B}$ & no & $\begin{array}{l}\text { decrease of FEV } 1>20 \% \text {, but decrease of PEF not } \\
\text { more than } 10 \%\end{array}$ & no \\
\hline 35 & 09.07 .2014 & $\mathrm{G}+++/ \mathrm{He}$ & yes & $\begin{array}{l}\text { first riding hour. Loss of reaction to curly horse in } \\
\text { subsequent riding hours combined influence of } \\
\text { pollen flight and curly horse }\end{array}$ & yes \\
\hline
\end{tabular}

Degree of flight: += weak; ++= middle; $+++=$ severe

Allergen: $\mathrm{G}=$ grass; $\mathrm{W}=$ willow; $\mathrm{R}=$ rye; $\mathrm{A}=$ alder; $\mathrm{H}=$ hazel; $\mathrm{B}=$ birch; $\mathrm{He}=$ herbal; $\mathrm{O}=$ oak; $\mathrm{M}=$ mugwort.

birth, having a more oval cross section in contrast to other horses with a round cross section [19].

Bowling in California did not succeed in establishing a Curly typical constellation in blood typing of 200 Curly horses [19].

It is not known whether the outer properties of this horse breed are responsible for the detected hypoallergenicity. Investigations of the skin of Curly horses by biopsy did not reveal any relevant histoanatomical differences to other horses [28].

The typical smell of Curly horses is different to other horses: Curly horses do not smell like horses. This may be an indicator for producing different proteins [30]. We observed in our Curly horses a very high sebum content of the skin compared to other horses. By this means the release of allergic skin dander may be reduced. This was also assumed from Felix et al. [27] as a possible reason for low allergenic potential.

Peak expiratory flow and lung function measurements The results of PEF and FEV1 measurements demonstrate a low influence of riding on Curly horses on lung function during and after riding. A significant relevant decrease was measured in only 3 cases on PEF or FEV1 of more than $-20 \%$ at horse contact during riding or after brushing. These were singular events in individual riders mainly in the start period of riding. These events could be reversed by simple inhalation of two puffs of salbutamol in every event. However, these events could not be observed in the further individual contact. During the further Curly horse contact we observed a loss of allergic reaction against these horses ( $\bullet$ Fig. 2). These results are in clear contrast to the empirical studies of animal workers in laboratory or in stables $[1,4]$, in which animal workers or riders have a greater possibility to be- come allergic against horses due to contact with these animals. The results of our study demonstrate that chronic contact to Curly horses does not induce an increasing risk of developing a stronger allergic reaction in nose, lungs or skin. Therefore, the general recommendation for horse allergic patients is to avoid further contact to horses [31] analogous to cats and dogs [32], but this cannot be proven by clear data [33-35]. Scientific studies on the effects of horse contact avoidance in horse allergic patients are lacking. On the other hand, other authors believe [36] that an intensive horse dander contact induces an immune tolerance in contrast to [1].

\section{PNIF}

The observed reactions in PNIF measurements are concordant with the results of PEF and FEV1 during and after riding and did not provide more information despite the fact that all of the investigated patients suffered from horse allergic rhinoconjunctivitis.

\section{Correlation of SPT and first riding hour results}

The SPT data show a mean lower wheal diameter when testing curly material compared to material of the German riding pony or the industrial test $\left(\right.$ Bencard $^{\circledR}$ ). The results of these tests did show a weak correlation to reaction of PEF or FEV1 in the first riding hour ( Table 2). Only the results of measurement at brushing these horses showed a good correlation to the diameter of wheal in the case of industrial test material and of straight Curly horse (ABC Curly P2563). This may be interpreted as an effect of increased horse dander liberation while brushing than while riding these horses. It may therefore support the theory that libera- 
tion of allergic dander is reduced in Curly horses due to an increased content of sebum in the skin of Curly horses (cf. Felix et al. [27]).

\section{Immune tolerance}

Our data demonstrate that the longer patients are riding on Curly horses the weaker the observed allergic reactions measured by PEF occurred ( $\bullet$ Fig.2). This supports the hypothesis that due to the lower allergenic potential it should be possible to induce an immune tolerance by regular contact to Curly horses after a period of 3 years (pts. $1+2$ of the study group have today a loss of horse allergy) - comparable to material, which is used for immunization against other allergens [36,37]. This hypothesis will be tested in a second Curly horse study which commenced in July 2014 [38].

\section{Conclusion}

The results of this study confirm the empirical observations that previously diagnosed horse allergic patients suffer from milder or even no allergic symptoms when riding on Curly horses. Furthermore, data also confirm the results of our pilot study [22] in a group of 40 horse allergic riders. Nevertheless, the results cannot be used to claim that Curly horses lack any allergenic potential. In this study we identified three patients, who had a clear deterioration of lung function (FEV1 and PEF) of more than $20 \%$ during or after riding or after brushing. However, these were singular events, which vanished after further riding hours. For one of our study patients we measured a complete loss of horse allergy after a three year period of riding hours every $4-6$ weeks. So we started a new study in 8-2014 in order to investigate this observation [38]. Riding on Curly horses for horse allergic riders can be recommended, if the precautionary methods of this study are observed.

$\begin{array}{ll}\text { Abbreviations } \\ \text { SPT } & \text { Skin prick test } \\ \text { ABC } & \text { American Bashkir Registry } \\ \text { PEF } & \text { Peak expiratory flow } \\ \text { FEV1 } & \text { Forced expiratory volume in one second } \\ \text { PNIF } & \text { Peak nasal inspiratory flow } \\ \text { SD } & \text { Standard deviation }\end{array}$

\section{Acknowledgements}

\section{$\nabla$}

We thank all the study participants and the staff (Susanne Mitlehner) in the study center.

We thank also Dr Alexander Mitlehner, Ph.D. (U. London), Wallingford, UK, for the help in preparing the manuscript.

\section{Conflict of interest}

$\nabla$

The authors declare that they have no conflict of interest.

\section{References}

1 Tutluoglu B, Atis S, Anakkaya AN et al. Sensitization to horse hair, symptoms and lung function in grooms. Clin Exp Allergy 2002; 32: $1170-$ 1173

2 Liccardi G, Salzillo A, Dente B et al. Horse allergens: An underestimated risk for allergic sensitization in an urban atopic population without occupational exposure. Respir. Med 2009; 103: 414-420

3 Liccardi G, D'Amato G, Antonicelli $L$ et al. Sensitization to horse allergens in Italy: A multicentric study in urban atopic subjects without occupational exposure. Int Arch Allergy Immunol 2011; 155: 412-417

4 Moghtaderi M, Farjadian S, Abbaszadeh Hasiri M. Animal allergen sensitization in veterinarians and laboratory animal workers. Occup Med 2014; 64: 516-520

5 Huwyler T, Wüthrich B. A case of fallow deer allergy. Cross-reactivity between fallow deer and horse allergy. Allergy 1992; 47: 574-575

6 Spitzauer S, Pandjaitan B, Söregi $G$ et al. IgE cross-reacitivities against albumins in patients allergic to animals. J Allergy Clin Immunol 1995; 96: $951-959$

7 Cabanas R, Lopez-Serrano MC, Carreira J et al. Importance of albumin in cross-reactivity among cat, dog and horse allergens. J Investig Allergol Clin Immunol 2000; 10: 71 - 77

8 Saarelainen S, Rytkönen-Nissinen M, Rouvinen J et al. Animal-derived lipocalin allergens exhibit immunoglobulin E cross-reactivity. Clin Exp Allergy 2008; 38: $374-381$

9 Nilsson OB, Binnmyr J, Zoltowska A et al. Characterization of the dog lipocalin allergen Can $\mathrm{f} 6$ : the role in cross-reacitivity with cat and horse. Allergy 2012; 67: 751-757

10 Al-Tameni SH, Al-Shidani AN, Al-Abri RK et al. The pattern of sensitization to inhalant allergens in Omani patients with asthma, allergic rhinitis and rhinoconjunctivitis. Sultan Qaboos Univ Med J 2008; 3: 319 324

11 Rönmark E, Bjerg A, Perzanowski $M$ et al. Major increase in allergic sensitization in schoolchildren from 1996 to 2006 in northern Sweden. J Allergy Clin immunol 2009; 124: 357-363

12 Novembre E, Mori F, Barni $S$ et al. Should the skin prick test to horse be included in the standard panel for the diagnosis of respiratory allergy? J Investig Allergol Clin Immunol 2009; 19: 247-249

13 Chapman MD, Wood RA. The role and remediation of animal allergens in allergic diseases. J Allergy Clin Immunol 2001; 107: S414-S 421

14 Baxi SN, Phipatanakul W. The Role of Allergen Exposure and Avoidance in Asthma. Adolesc Med State Art Rev 2010; 21: 57-71

15 Fernandez-Tavora L, Rico P, Martin S. Clinical experience with specific immunotherapy to horse dander. J Investig Allergol Clin Immunol 2002; $12: 29-33$

16 Nanda A, Wasan AN. Clinical assessment of allergen immunotherapy with different doses of horse extract. Ann Allergy Asthma Immunol 2014: 112,76 (letter)

17 Gottlöber P, Gall H, Peter RU. Specific immunotherapy with animal epithelial cells. Allergo J 2000; 9: 217-220

18 Kürschner A. Anamnese und in-vitro-allergologische Untersuchungen bei Pferdeallergien und Toleranz gegenüber Curly horses. Dissertation, 2-2004, Med. Fakultät, Rheinisch-Westfälische Technische Hochschule, Aachen.

19 Thomas S, Gaier D, Bowling A. Myth and Mystery: The Curly Horse in America. C.S. Fund Inc. 1989

20 www.abcregistry.org

21 www.ichocurlyhorses.com

22 Mitlehner W. Allergy against horses: Are curly horses an alternative for horse-allergic riders? Allergo J 2013; 22: 244-251

23 Rueff F, Bergmann KC, Brockow K et al. Hauttests zur Diagnostik von allergischen Sofortreaktionen (Leitlinie). Allergo J 2010; 19: 402 - 415

24 AWMF. Hauttests zur Diagnostik von allergischen Soforttyp-Reaktionen, Nr.061/26, 10/2009.

25 Elfman L, Brännström J, Smedje G. Detection of horse allergen around a stable. Int Arch Allergy Immunol 2008; 145: 269-276

26 http://www.allergie.hexal.de/pollenflug/historie/

27 Felix K, Ferrandiz R, Einarsson R et al. Allergens of horse dander. Comparison among breeds and individual animals by immunoblotting. J Allergy Clin Immunol 1996; 98: 169-171

28 Sponenberg DP. Dominant curly coat in horses. Gent Sel Evol 1990; 22 : 257-260

29 Scott $D W$. Skin of the neck, mane and tail of the curly horse. Equine Veterinary Education 2004; 16: 201 - 206 
30 Pers communication: Dr. agr. Monika Reißmann, Molekularbiologisches Zentrum, Albrecht Daniel Thaer-Institut, Lebenswissenschaftliche Fakultät, Humboldt-Universität zu Berlin.

31 Dürr C, Helbling A. Allergies to animals and fungi. Ther Umsch 2012; 69: $253-259$

32 Portnoy JM, Kennedy K, Sublett JL et al. Environmental assessment and exposure control: a practise parameter-furry animals. Ann Allergy Asthma Immunol 2012; 184: 223.e1 -223.e15

33 Lødrup Carlsen KC, Roll S, Carlsen KH et al. Does pet ownership in infancy lead to asthma or allergy at school age? Pooled analysis of individual participant data from 11 European birth cohorts. PLoS One 2012; 7: e43214. DOI 10.1371/journal.pone.0043214 [Epub 2012 Aug 29]

34 Millqvist E, Johansson A, Månsson T et al. A prospective study of allergy development in 158 children and 128 adults with new extensive exposure to furred animals. Clin Exp Allergy 06 2007; 37: 948 - 953

35 Dick S, Friend A, Dynes $K$ et al. A systematic review of associations between environmental exposures and development of asthma in children aged up to 9 years. BMJ Open 2014; 4: e006554. DOI 10.1136/ bmjopen-2014-006554

36 Hesselmar B, Aberg B, Eriksson B et al. Allergic rhinoconjunctivitis, eczema, and sensitization in two areas with differing climates. Pediatr Allergy Immunol 2001; 12: 208-215

37 Kleine-Tebbe J, Bufe A, Ebner C et al. Die spezifische Immuntherapie (Hyposensibilisierung) bei IgE-vermittelten allergischen Erkrankungen. Leitlinie der Deutschen Gesellschaft für Allergologie und klinische
Immunologie(DGAKI), des Ärzteverbandes Deutscher Allergologen (Ä DA), der Gesellschaft für Pädiatrische Allergologie und Umweltmedizin (GPA), der Österreichischen Gesellschaft für Allergologie und Immunologie (Ö GAI) und der Schweizerischen Gesellschaft für Allergologie und Immunologie (SGAi) Allergo J 2009; 18: 509-537

38 Pfaar O, Bachert C, Bufe A et al. Guideline on allergen-specific immunotherapy in IgE-mediated allergic diseases - S2k Guideline of the German Society for Allergology and Clinical Immunology (DGAKI), the Society for Pediatric Allergy and Environmental Medicine (GPA), the Medical Association of German Allergologists (AeDA), the Austrian Society for Allergy and Immunology (ÖGAI), the Swiss Society for Allergy and Immunology (SGAI), the German Society of Dermatology (DDG), the German Society of Oto-Rhino-Laryngology, Head and Neck Surgery (DGHNO-KHC), the German Society of Pediatrics and Adolescent Medicine (DGKJ), the Society for Pediatric Pneumology (GPP), the German Respiratory Society (DGP), the German Association of ENT Surgeons (BV-HNO), the Professional Federation of Paediatricians and Youth Doctors (BVKJ), the Federal Association of Pulmonologists (BDP) and the German Dermatologists Association (BVDD). Allergo J Int 2014; 23: 282-319

39 Mitlehner W, Mitlehner HC. Immuntolerance induction by Curly horses in horse allergic riders. Leads a three-year equestrian contact exclusively to Curly Horses to an immune tolerance development? (Ethics revue committee) Ärztekammer Schleswig Holstein (general medical council) $046 / 14$ 